\title{
PSYCHOLOGICAL ASPECTS OF MANIPULATION WITHIN AN INTERPERSONAL INTERACTION: MANIPULATIONS AND MANIPULATORS
}

\section{Hrebin N. V., Shyroka A.}

\section{INTRODUCTION}

The phenomenon of manipulation has long attracted the attention of scientists - theorists and practitioners in various fields. It still attracts their attention, especially in times of informational outbreak, latest information technologies and industrial development, during rapid technical and technological progress, in times of reorientation of an individual to the market type of interaction and transformation of the individual's value system. In the light of this agenda, we find it necessary to consider manipulation as a means of hidden control and to outline the key features by which it can be differentiated from other methods of influence; to compare the approaches used by various authors to the understanding of manipulation, and to analyse reasons for the personality development of a modern manipulative person as well as his/her typical psychological characteristics.

Trying to define the concept of "influence", researchers often refer to such a scientific category as "interaction" and to the concept of "interinfluence" derived from it ${ }^{1}$. Today, a generalized attitude to influence as an element of psychological interaction is observed, which often leads to the assimilation of these concepts ${ }^{2}$. In psychological dictionaries, influence during interaction is viewed as a process when an individual is changing the behaviour of another person as well as his/her attitudes, intentions, ideas, as a result of the person's activity $^{3,4}$. The concept of psychological impact (or psychological influence) is narrower; it is regarded as one of the options for impact in general. The singling out of this category is based on 'cause and effect' changes in the

\footnotetext{
${ }^{1}$ Fundamentals of Social Psychology: A Textbook. Edited by M. M. Sliusarevskyi. Kyiv : Millennium. 2008. P. 174.

${ }^{2}$ Volynets P. P. The criteria for latent psychological impact. The actual problems of psychology: Collection of scientific works Volume 7. Environmental Psychology. 2010. Issue 22. P. 15.

${ }^{3}$ Psychology. Dictionary. Under general editorship of A.V. Petrovskyi, M.G. Yaroshevskyi. Moscow : Prosveshcheniye. 1990. P. 53.

${ }^{4}$ Dictionary-Reference work on Social Psychology. Under general editorship of V. Krysko. St. Petersburg : Piter. 2003. P. 42.
} 
person's mind (psychological characteristics of the individual, group norms, public opinion, etc.) as a result of the influence on him/her ${ }^{5}$.

The psychological impact involves the influence on the consciousness, feelings, actions of another person using exclusively psychological means (verbal, paralinguistic, non-verbal ones) and providing the opportunity and time to respond to this impact ${ }^{6}$. Tetyana Kabachenko emphasizes that we deal with the psychological impact when it has external origin in relation to the recipient, and reflected in him/her, it leads to a change in the psychological regulators of human activity ${ }^{7}$. Vitaliy Tatenko considers the phenomenon of influence from an ontological point of view and defines it as a way of subjective-behavioural action on another person, as a special action that generates the event of being ${ }^{8}$.

There are numerous attempts to develop of a typology of psychological impact made by various authors, which is an urgent problem in modern psychological science, since there is a need to systematize the criteria by which it would be possible to differentiate the types of impact, to analyse the conditions that ensure the effectiveness of their application. One of the criteria for classifying psychological impact methods is the dependence on openness to the recipient of the means of influence and the purpose of the impact. According to this criterion, the psychological impact can be divided into explicit (open) and implicit (covert, or latent). Psychological impact is explicit when its goals are communicated in advance and are not hidden. Implicit, or covert psychological interaction is a reciprocal influence whose goals are not declared or are disguised as the goals of open interaction, so the recipient makes a decision (or performs an action) planned by the initiator of the impact $^{9,10}$.

\section{Revisiting the issue of defining manipulation as a type of hidden psychological impact}

B. Bessonov, L. Proto, G. Shiller identify the content of implicit (covert) psychological influence as the content of manipulation, emphasizing its

\footnotetext{
${ }^{5}$ Kabachenko T.S. Methods of psychological impact. Moscow. 2000. P. 13.

${ }^{6}$ Sidorenko E.V. Training on influence and resistance to influence. St. Petersburg: Rech. 2002. P. 11-12. P. 23.

${ }^{7}$ Kabachenko T.S. Methods of psychological impact. Moscow : Pedagogical Society. 2000.

${ }^{8}$ Tatenko V.O. Psychology of influence: subjective paradigm. Scientific studies in Social and Political Psychology. Kyiv: Stal, 20. Vol. 3 (6). P. 3-18.

${ }^{9}$ Sidorenko E. V. Training on influence and resistance to influence. St. Petersburg: Rech. 2002. P. 11-12.

${ }^{10}$ Sheinov V.P. Hidden control over a person. The psychology of manipulation. Minsk: Harvest, 2000. P. 3-4.
} 
destructive characteristics. The latent impact can pursue various goals and intentions of the initiator, Viktor Sheinov believes. When both the recipient of the influence and the manipulator are in a 'win-win' situation, such a covert influence is called assertive, as it does not aim to harm another person but serves as an opportunity for a person to confidently and worthily assert his/her rights (without oppressing the rights of others). When the recipient of the influence is the gainer, while its initiator loses, - we are talking about the altruistic covert impact. When only the initiator stands to gain, it occurs as a result of the egoistic covert influence (manipulation) ${ }^{11}$. Thus, the author focuses on the negative aspect of manipulation. In the works by E. Dotsenko, O. Sydorenko, J. Rudinov, K. Fopel, E. Shostrom, a possible positive role of manipulations is outlined. In particular, according to K. Fopel, we are talking about a variety of possibilities of influence with which people pursue fair goals ${ }^{12}$.

The concept of manipulation has a direct and metaphorical meaning. The word "manipulation" (from the Latin manipulare) has long been used in a purely positive sense: "to manage with skill, competently". The transition to the metaphor was the use of this term in relation to the demonstration of various tricks and card games where, in addition to dexterity, concealing actions or true intentions, as well as carrying out all kinds of distracting procedures that divert the observers' attention, is appreciated. Subsequently, they began to understand manipulation (in its indirect sense) as the desire to "snatch control" of another person, "to hook", "an attempt to turn a person into an obedient weapon, into a puppet". Later, the metaphor of manipulation is supplemented with the following characteristics: mastery of its performance and the creation in a person of the illusion of independence of decisions made and actions $\operatorname{taken}^{13}$. Today, manipulation is used in the context of interpersonal relations and in the area of controlling mass (popular) consciousness. M. Babiuk points out that manipulation is in the interweaving of many social relations; it is in contact with such phenomena of human life as social management, cooperation, rivalry and the like. The urgent problem of determining the content of manipulation is that it is different when different approaches are used, so the author's position leaves its significant imprint on the definition of the main content of this concept. In psychological literature,

\footnotetext{
${ }^{11}$ Sheinov V. P. The psychology of manipulation. - Minsk : Harvest, 2009. P. 9-10.

12 Fopel K. Confident management. Training, coaching, self-development. Moscow : Genesis, 2004. P. 83.

13 Dotsenko E.L. Psychology of manipulation: phenomena, mechanisms and defence. Moscow: CheRo, Publishing House of MSU, 1997. P. 43-47.
} 
the key emphasis is placed on interpersonal manipulation; the main attention is paid to the mechanisms of mental influence. In political science, such a phenomenon is considered in the context of events occurring "here and now", respectively, the analysis is often limited to current reality ${ }^{14}$.

According to H.W. Franke, manipulation is a psychological impact carried out covertly, to the detriment of the people targeted. B. Bessonov considers manipulation as a form of spiritual influence, hidden domination, and control of people, with occurs by non-violent method $^{15}$. S. Elvein, who understands manipulation as spiritual management, emphasized that manipulation is coercion, the instrument of which is irrational and emotional means. J. Rudinow defined the manipulative impact as the inducement of certain behaviour through deception, playing on human vulnerabilities. The definitions formulated by M. Ames \& A.H. Kidd also emphasize the use of subtle, barely noticeable or non-physically aggressive means in manipulation, such as lying, bribery or intimidation. Other authors (O. Yokoyama, V.Znakov, V. Sagatovskiy) emphasize the manipulator's attitude towards others as an instrument, as a means, as well as acting for his/her own benefit, neglecting the true interests of people who are subject to the manipulative impact ${ }^{16}$. The original explanation of manipulation is given by W.H. Riker. According to him, this is such a structuring of the world that allows its leader to $\operatorname{win}^{17}$. O. Sydorenko has defined manipulation as an intentional and covert provocation of another person to experience certain conditions, make decisions and/or perform actions necessary for the initiator to achieve his/her own goals ${ }^{18}$.

$\mathrm{N}$. Kondratyeva highlighted several aspects of manipulating a person in the modern society, in particular, the provisions that all people use manipulation, that it can be both conscious and unconscious, but always with a negative connotation, that it is easier to manipulate a person in a crowd. We consider it necessary to review these provisions in more detail, to analyse them from the standpoint of different authors.

1. Everyone is manipulating without exception, and constantly, but to a different extent. Everything is used in manipulations - from the most

14 Babiuk M.I. Social Manipulation (Philosophical Analysis) Author's Thesis. Moscow. 2004. P. 9.

${ }^{15}$ Bessonov B.N. The ideology of spiritual suppression. - Moscow: Publishing house of Moscow State University (MSU), 1971. P. 110.

${ }^{16}$ Sheinov V.P. The psychology of manipulation. Minsk : Harvest, 2009. P. 6-7.

${ }^{17}$ Riker, W.H. The Art of Political Manipulation Text. London : Yale University Press, 1986. P. 39.

${ }^{18}$ Sidorenko E.V. Training on influence and resistance to influence. St. Petersburg: Rech. 2002. P. 49. 
commonplace methods to tricks ${ }^{19}$. Even François De La Rochefoucauld said that "Men would not live long in society were they not the dupes of each other"20.

The same opinion is shared by D. Dudinskiy who believes that each of us, in a given situation, uses direct or covert methods of psychological influence to achieve own goals ${ }^{21}$. Such a context implies that, firstly, people still differ in their propensity to manipulate. Secondly, the internal actualizer can defeat the manipulator inside a person (the only question is how long and under what conditions the advantage will be stored).

2. Manipulations can be either unconscious or conscious and targeted. During an unconscious manipulation, a person does not realize that he/she is trying to put pressure on others - this happens automatically ${ }^{22}$. People often seek to influence because they defend their interests and meet their needs, and not because the truth is fully revealed to them and they feel that they have the right to decide for others ${ }^{23}$. Therefore, manipulations are often applied unconsciously, which however does not reduce their effectiveness. On the other hand, Olena Sydorenko considers the criterion of awareness / unconsciousness to be very uncertain, as are the areas themselves. As an example, the researcher cites Eric Berne's view that manipulation is carried out consciously by the manipulator, while the game is played by the player unconsciously, but the concept of the game is extremely broad and includes the concept of the psychological game, which Berne calls manipulative ${ }^{24}$. The most striking example of conscious manipulation is advertising. Specialists in this field adhere to the principle of selling not a product, but a need (that is, a person should perceive the product in such a way that it will satisfy his/her needs). For example, the advertisement of soft drinks is indisputably manipulative, where the "natural, genuine product" is associated with ideas about youth, health, and cheerfulness.

3. Manipulation is always negative ${ }^{25}$. We have examined the approaches of various authors to the concept of manipulation. Accordingly, most of them

${ }^{19}$ Kondratyeva M.V. Manipulating a person in the modern world. URL: http://science.ncstu.ru/conf/past/2009/region13/theses/ppsl/068.pdf/file_download

${ }^{20}$ La Rochefoucauld F. de. Maxims and moral reflection. Sentences and aphorisms. Moscow, 1990. P. 42.

${ }^{21}$ Dudinskiy D.I. 30 ways of manipulating and managing people. Minsk: Harvest, 2004. P. 14.

${ }^{22}$ Kondratyeva M.V. Manipulating a person in the modern world. URL: http://science.ncstu.ru/conf/past/2009/region13/theses/ppsl/068.pdf/file_download

${ }^{23}$ Golovakha E.I., Panina N.V. The psychology of human mutual understanding. Kyiv, 1989. P. 18.

${ }^{24}$ Sidorenko E.V. Training on influence and resistance to influence. St. Petersburg: Rech. 2002. P. 62.

${ }^{25}$ Kondratyeva M.V. Manipulating a person in the modern world. URL: http://science.ncstu.ru/conf/past/2009/region13/theses/ppsl/068.pdf/file_download 
emphasize the immorality of manipulation, the crime of intervention in the inner world of a person.

Shostrom, Rudinov, Dotsenko deprive the manipulation of an extremely negative assessment. Its possible positive role can be traced in their works. In particular, Shostrom noted that not every manipulation is evil; some manipulative steps are necessary for a person in his/her struggle for existence, but much of the manipulation is very detrimental to the manipulators themselves and their relatives ${ }^{26}$. There are many examples where manipulative actions are performed with an altruistic goal (in particular, a physician who uses a placebo instead of drugs and authoritatively assures the patient of the effectiveness of the pacifier - the manipulative method works: the patient, through autosuggestion, actively mobilizes his/her internal reserves and recovers), finally psychotherapeutic actions can be manipulative in nature. V. Sheinov called this covert impact constructive, not manipulative. If the actions of the initiator are carried out in the interests of the recipient, then this is a socially approved hidden influence; if they are selfish, - it is a manipulation that is condemned in the public consciousness ${ }^{27}$. However, in the opinion of R. Goodin, human actions are considered to be manipulative not just because that they contradict the interests of another person, but because they contradict their will ${ }^{28}$.

4. Manipulating a person is easier in a situation when he/she is in a crowd, because inside the crowd the mechanisms of mutual suggestibility, emotional contagion, and unconscious imitation of each other are especially powerful ${ }^{29}$. A "temporal paralysis" of rational thinking occurs in the crowd, and people might be willing to follow a pattern - this is a pattern (idea, or behaviour) that a manipulator can easily implement based on important needs, feelings, and states of people.

E. Dotsenko has analysed in detail the characteristics of manipulation that were adopted by various authors, and generalized them into integral criteria that can be relied upon in defining the very concept of interpersonal manipulation:

1) generic indicator is the psychological impact. This criterion covers the following features: "indirect influence", "spiritual influence", "programming of thoughts, intentions", "focus on the spiritual state, inner world";

${ }^{26}$ Shostrom E. Anti-Carnegie, or Man, the Manipulator. Moscow: Double-V, Delta-92, 1998. P. 20.

${ }^{27}$ Sheinov V.P. The psychology of manipulation. - Minsk : Harvest, 2009. P. 8.

28 Dotsenko E.L. Psychology of manipulation: phenomena, mechanisms and defence. Moscow: CheRo, Publishing House of MSU, 1997. P. 53.

29 Kondratyeva M.V. Manipulating a person in the modern world. URL: http://science.ncstu.ru/conf/past/2009/region13/theses/ppsl/068.pdf/file_download 
2) attitude to the object of manipulation as a means of achieving one's own goals, due to which the hidden goals of the manipulator are achieved, hi/hers interests and own needs are realized, without taking into account the interests, will, desire of the other side - the person who acts as the object of manipulation.

3) the desire to get a one-sided $\operatorname{win}^{30}$. This criterion is quite contradictory, because manipulative influence can be carried out in the interests of another person, for example, so that someone quits a bad habit. For instance, a wife manipulates to force her husband to stop drinking alcohol, which harms his physical and mental health. Of course, she pursues her own interests (after all, life with her alcoholic husband has turned into hell), but in the end she seeks to prevent the degradation of the personality and the loss of health of the drunkard (even against his own will);

4) the covert nature of the impact (the fact of the impact itself, its orientation). Such a criterion is also contradictory and ambiguous. An attempt to manipulate has a chance of success if the fact of influence is not recognized by the recipient. It can be assumed that unconsciously a person feels when he or she is becoming a victim of manipulation, but for various reasons he/she does not allow danger signals to be realized. According to Rudinov, manipulation ceases to be itself if the illusion of who wants what is lost;

5) using psychological strength, practising on weaknesses (playing on psychological vulnerability). This criterion is quite relative, because force is a necessary element of any influence; therefore it is not an indicator that would differentiate between types of influence;

6) impulse, motivational introduction (the formation of "artificial" needs and motives for changing behaviour in the interests of the initiator of manipulation). Not every impulse indicates manipulation, but only when the manipulator imposes on the recipient new goals that he/she previously did not have. That is, the sign of manipulation is not a reflexive guessing but the desire to create a new motivation;

7) skill in performing manipulative actions ${ }^{31}$. According to Sydorenko who has compared the manipulators to musicians who play the balalaika or harp, the skill of the manipulators can be different. A manipulator - harpist is more inventive, he/she grasps individual strings of each person and tugs at them intentionally. A manipulator who "plays the balalaika" sees only three strings in others (for example, fear, desire, and interest), but also successfully

30 Dotsenko E.L. Psychology of manipulation: phenomena, mechanisms and defence. Moscow: CheRo, Publishing House of MSU, 1997. P. 51-58.

${ }^{31}$ Ibid, P. 57. 
squeezes the desired melody from his/her instrument ${ }^{32}$. Therefore, skill (or mastery) can only be a relative attribute that characterizes the very subject of manipulation.

Based on these criteria, E. Dotsenko has formulated the definition of manipulation: manipulation is a type of psychological impact, the skilful execution of which leads to the latent excitement of another person's intentions that do not coincide with his/her actual existing desires ${ }^{33}$.

\section{Types and mechanisms of manipulative impact}

E. Dotsenko has identified the following types of manipulation, which differ in the means of psychological influence and in the nature of intrapersonal processes:

1) perceptually oriented manipulation;

2) conventional manipulation;

3) operational-object manipulation;

4) inference-oriented manipulation;

5) manipulation focused on personality structures;

6) manipulation with spirituality.

Perceptually oriented manipulation is based on an associative mechanism that arises between the image and its relevant need, aspiration or motivational attitude. Manipulative techniques are based on the presentation of such incentives that actualize the need required by the manipulator ${ }^{34}$.

Advertisers very often present products, linking them with certain emotional images that actualize the needs and states of an individual. We have already provided examples of advertisements in which drinks are presented along with a good and fun way of spending free time with real friends. That is, it is not a drink that is sold, but a need that is satisfied by its purchase.

Conventional manipulation is provided by rules, taboos, social norms, scenarios, role positions and the like. An example of such manipulation is the situation from the book by V. Tsvetov "The Fifteenth Stone of the Ryoanji Garden". Manipulation is based on the Japanese social norm, namely workaholism. A man (one of the protagonists) received an advance personal day off in the middle of the work week because he had been working without any days off for a long time. With the beginning of the working morning, when the entire male population in the quarter "died out", the news very quickly spread among the women that the man had stayed at home.

${ }^{32}$ Sidorenko E.V. Training on influence and resistance to influence. St. Petersburg: Rech. 2002. P. 50-51.

33 Dotsenko E.L. Psychology of manipulation: phenomena, mechanisms and defence. Moscow: CheRo, Publishing House of MSU, 1997. C. 59.

${ }^{34}$ Ibid, P. 157. 
Subsequently, gossip reached the mother of the book hero, who made a real fuss of her son: "Normal men should be at work on working days!" The man (after all, he still wanted to be "normal") could not stand it and after a few hours went to work ${ }^{35}$.

Involvement in operational-object manipulation occurs through the use of such automatisms as the power of habit, inertia, skills, and action logic. A very good example in this case is Krylov's fable "The Crow and the Fox". The Fox skilfully led the Crow to make her want to open her mouth, although not in order to give cheese, but to demonstrate her singing talent. Filled with compliments, waiting for the next one (by inertia), the Crow lost her vigilance, and with it, food ${ }^{36}$.

Inference-oriented manipulation works through the following mechanisms of involvement: cognitive scheme, internal logic of the situation, patterns of cognitive processes, and cognitive attitudes. The background factor is the removal of cognitive dissonance, while hints, imitation of the problemsolving process act as motives (impulses). As an example, V. Sheinov considers Detective Colombo who reported some information to the criminal (whom he exposed, but lacked evidence to apprehend him), prompting him to destroy evidence, and, accordingly, caught the criminal for doing so ${ }^{37}$.

The manipulative impact focused on personality structures is characterized by the actualization of an interpersonal conflict, when the recipient of the manipulation is held responsible for the choice made through suffering in doubt. Dotsenko rightly called this type of manipulation the exploitation of the personality, because here the deep essence lies in the desire to shift the responsibility for the committed actions to the recipient, while the manipulator gets the $\operatorname{win}^{38}$. In this case, it is extremely important for the manipulator to create an illusion of choice for the agent of influence. Personal choice has always stood out as somewhat desirable; it has always been linked to human freedom. When a person is sure that he/she is acting of his/her own free will, he/she will do much more than when he/she knows that he/she is fulfilling someone else's decision imposed on him/her.

Using various means of covert influence, such as truism (an opinion is presented as a banality, obvious truth, etc.); "the illusion of choice" (the choice is given in details, but not in the core); "providing all the options"

${ }^{35}$ Gladyshev S.A. How to survive in a crowd and remain yourself. Rostov-on-Don: Phoenix, 2004. P. 189.

${ }^{36}$ Dotsenko E.L. Psychology of manipulation: phenomena, mechanisms and defence. Moscow: CheRo, Publishing House of MSU, 1997. P. 161.

${ }^{37}$ Sheinov V.P. The psychology of manipulation. Minsk : Harvest, 2009. P. 138.

38 Dotsenko E.L. Psychology of manipulation: phenomena, mechanisms and defence. Moscow: CheRo, Publishing House of MSU, 1997. P. 165. 
(the person is provided with all the options, but gestures, facial expressions indicate which suits him/her best), the manipulator brings the person to a specific decision that is favourable to the first. As a result, the recipient who is subject to manipulation feels like the author of the decision and voluntarily takes responsibility for his/her act.

The spiritual exploitation-oriented manipulation is a form of covert psychological influence in which the main methods of motivation are the actualization of existing values, pushing towards meaningful destabilization, soul searching and reappraisal of values, imitation of the search for raison d'etre $^{39}$. The tactic of involving new members in sectarian organizations is of a manipulative nature, since it requires a review of the value-orientation sphere and the purpose of existence. When the object of influence is disoriented, confused, uncertain, he/she is offered a new meaning (filled with the illusory fulfilment of desires, satisfaction of needs, etc.).

The above types of manipulative impact should not be considered as a hierarchical structure: the author analyses them as various mechanisms that can be combined, complement each other, increasing the effectiveness of the impact.

When Robert Cialdini analysed the strategies of social manipulation, he described the following mechanisms that contribute to the success of manipulation: Reciprocity (the rule of mutual exchange); Commitment/Consistency; Social proof; Linking (benevolence); Authority; Scarcity; Automatic behaviour (focus on stereotypical thinking) ${ }^{40}$.

In accordance with the Reciprocity rule, a person seeks to pay in some way for what he/she received from another person. "A small gift from the company" is designed precisely to ensure that a person does not want to offend a company representative who kindly gives it. Then this person is more likely to purchase products that are already offered for money.

Psychologists have long understood the importance of the Consistency principle in managing people. L. Festinger, F. Heider, T. Newcomb consider people's desire for consistency to be the main motivator of behaviour. The desire to be (or look) consistent is a powerful weapon of influence. Robert Cialdini and his colleagues conducted a field experiment in which a fake theft of a radio was staged on the beach in order to see if there were many strangers who would try to stop the robber. In the first experimental situation, when strangers saw and understood the fact of theft, only four out of twenty people rushed after the robber. In the second experimental situation,

\footnotetext{
${ }^{39}$ Sheinov V.P. The psychology of manipulation. Minsk : Harvest, 2009. P. 139.

${ }^{40}$ Cialdini R. Psychology of influence. St. Petersburg: Piter, 2000. URL: http://www.gumer.info/bibliotek_Buks/Psihol/Chiald/_Index.php.
} 
the conditions were changed: the owner of the things (an experimenter assistant) asked strangers to look after his things and left for a while. In nineteen out of twenty cases, people rushed after the thief, stopped him, snatched out a radio, and demanded an explanation. The point is that when a person assumes responsibility for taking certain actions, he/she seeks to be consistent in this, even in conditions that force decisive steps, such as in the given experiment.

The Social proof mechanism works when, for example, sellers tell customers that products are "selling out extremely quickly". You do not need to convince a person that the product is good, it is enough to say that most people think so. One of the conditions for this is the lack of confidence of the individual. Without a doubt, when people do not feel confident, they tend to focus on the actions of others in order to decide how to act for themselves.

According to the principle of Scarcity, people value the thing that is less accessible. Reporting a limited number often becomes a manipulative step to increase the value of a particular item, or at least arouse interest in it.

The manipulative mechanism described by Cialdini as Linking lies in the fact that the one who arouses sympathy and trust in a person (in a word - a good friend) is able to exert the most effective influence on the person. Employees of charitable organizations attract those who live nearby as members, because it is much more difficult to turn away a friend or neighbour than a complete stranger.

David Myers notes that people tend to sympathize with those who look like them. In addition, people respond better to messages that come from a member of the same social group ${ }^{41}$. This pattern is used in manipulative techniques based on the attractiveness of the so-called "granfalloons" (meaningless associations of people according to a certain criterion). An example of a granfalloon can be a group of "Taureans" - people united by one zodiac sign, a group of "men who love cooking" and others. People of the same granfalloon seem to be more attractive and trustworthy to each other. The manipulative impact on people in this group can be much more effective if the manipulator is also a member of that granfalloon (which, by the way, can be created by him/her) ${ }^{42}$.

The mechanism described by R. Cialdini as a powerful source of influence is the impact of Authority. The results of numerous experiments (in particular, Milgram's experiments) indicate an extremely pronounced readiness of adults to give in, following the instructions of authority. Studies have also shown that

\footnotetext{
${ }^{41}$ Myers D. Social Psychology. St. Petersburg: Piter, 2000. P. 319.

${ }^{42}$ Aronson E., Pratkanis E. R. Age of Propaganda: Mechanisms of persuasion, everyday use and abuse. St. Petersburg: Prime-EUROSNAK, 2003. P. 234-237.
} 
individuals who have certain symbols of authority are treated by others with great respect. An example of such a mechanism is how pharmaceutical companies promote their products to the market using a character in a white coat who authoritatively states that most doctors recommend using this particular medicine.

Another manipulative mechanism is the use of stereotypes. Automatic, stereotyped behaviour prevails among people because in many cases it is most appropriate: we need shortcuts in today's extremely diverse world. One often has to use stereotypes to classify things according to certain key features and then to react without hesitation when he/she encounters a certain feature that plays the role of a trigger ${ }^{43}$. For example, when a person comes to a large supermarket, he/she is faced with a wide range of goods from different manufacturers. Confused by the variety and quantity, a person can take advantage of the well-known stereotype of "the more expensive, the better" and purchase a product without having a look at its components (which, by the way, are often similar to the components of cheaper products). It is also worth noting that the effectiveness of the impact depends not only on the technological side but also on the personality of the manipulator - his/her psychological traits, authority, social status and other parameters discussed below.

\section{Factors of the formation of a manipulative individual}

When analysing the ways an individual - manipulator is formed, various authors emphasize the primacy of a certain factor. The inevitability of spiritual manipulation is derived from the modern technical world by the philosopher and sociologist $H$. Marcuse who believed that it is the technicalization of society that generates manipulators, it is technology that rationalizes human bondage and indicates the technical impossibility of being autonomous and able to determine one's own life.

According to E. Dotsenko, the formation of the personality of the manipulator is facilitated by the following "cultural assets": struggle as a value, cheating as an example of one of the possible means of struggle. A person accepts and actively uses the slogan (of course, disguised) "you can cheat, you need to cheat, cheating means winning!", brings it to automatism and reaches the deepest semantic foundations of the personality ${ }^{44}$.

Shostrom agrees with F. Perls who believes that the main reason for manipulative behaviour is an internal personal conflict: trusting oneself or the external environment. The manipulator cannot completely trust either

\footnotetext{
43 Cialdini R. Psychology of influence. St. Petersburg: Piter, 2000. URL: http://www.gumer.info/bibliotek_Buks/Psihol/Chiald/_Index.php.

44 Dotsenko E.L. Psychology of manipulation: phenomena, mechanisms and defence. Moscow: CheRo, Publishing House of MSU, 1997. P. 66-67.
} 
him/herself or others, therefore, he/she clings to them, tries his/her best to control them, elaborates a manipulative style of relationship.

According to Erich Fromm, the factor of manipulative behaviour is a person's misunderstanding of the essence of true love, which involves achieving a productive orientation. In this orientation, a person overcomes the omnipotent narcissistic desire to exploit others, manipulate them, and gains faith in one's own strengths ${ }^{45}$.

The existentialists (J. Bugental) saw the main reason for the formation of a manipulative personality in its helplessness in the face of an unpredictable and risky world. In search of stability, the passive manipulator adopts the position: "if I cannot control something, then I won't; let others do it for me", while the active manipulator, overcoming anxiety, seeks to make everyone around him/her dependent on him/herself.

Such factors as fear of an adversity (J. Haley \& W. Glasser), uncritical aspiration to receive approval from the world (A. Ellis) can also contribute to the formation of a manipulative personality ${ }^{46}$.

It is impossible to disagree with E. Shostrom who believes that a child is not born but becomes a manipulator, and very early. The first manipulative scenarios are always scenarios of parent-child relationships. Often, parents manipulate based on their child's fear: "If you don't behave yourself, I will leave you alone!" The child grows up and learns this scenario of behaviour, because it is so effective in situations when you need to achieve your goal. The following example illustrates a child's use of fear-based manipulation: "If you do not give me the doll, then I will go away and I will not play with you," says the older sister to the younger one. The younger sister, out of fear that she will be left alone in the game, gives the doll to the older sister: "here you are, just don't leave, play with me!" The manipulation is complete and perfect. Even in childhood, parents can impose an illusory understanding of love: "the more perfect you are, the more beloved you are". An example is parental behaviour like, "I love you when you get good grades". In the future, the motivational orientation towards perfectionism forces one to fight for the much-needed parental love and acceptance, using manipulative strategies of behaviour. The tendency to manipulate correlates with the motivational attitude of a person to the result of activity ${ }^{47}$. The explanation for this

\footnotetext{
${ }^{45}$ Fromm E. The Art of Loving. Moscow: Republic, 1992. P. 109-178.

${ }^{46}$ Shostrom E. Anti-Carnegie, or Man, the Manipulator. Moscow: Double-V, Delta-92, 1998. P. 5-9.

${ }^{47}$ Hrebin N.V. Motivational attitudes of persons prone to manipulate in interpersonal relationships. Problems of Modern Psychology: Collection of Research Papers of KamianetsPodilskyi Ivan Ohienko National University, G.S. Kostiuk Institute of Psychology at APS of Ukraine / Ed. by S.D. Maksymenko, L.A. Onufriyeva. Issue 4. Kamianets-Podilskyi: Axioma, 2009. P. 46.
} 
connection may be a distorted understanding of love: "when I achieve the result, I am good, which means I am loved and accepted".

Under adverse conditions, parental responsibility for a child degenerates into a feeling of omnipotence and total control: "you must, you must not..." When a child does not live up to expectations, parents successfully manipulate the feelings of guilt, love, and fear: "you ought to be ashamed for being such a person". Other parental manipulative techniques include comparisons: (our neighbours' daughter... but you...), promises, lures (I will give you... when you do as I say) and many others. Later, children apply the most effective parental manipulations, modified and adapted to their abilities.

\section{Propensity of a person to manipulate in interpersonal relationships}

In addition to differentiating manipulations from other types of psychological influence, an important issue from practical and theoretical point of view is a person's propensity for manipulation in interpersonal relationships, since stable and long-lasting behavioural trends begin with predispositions. The propensity to manipulate is considered as the person's willingness to use other people to achieve his/her own goals ${ }^{48}$. When manipulation is used as a dominant strategy of behaviour, the propensity to manipulate reaches the level of Machiavellianism.

The concept of "Machiavellianism" was originally introduced to refer to politics, which contradicts moral standards. This standpoint is reflected in the views of the Italian scientist, politician Nicolo Machiavelli, and is justified in his work "The Prince" $"$. The views on Machiavellianism as a psychological category are ambiguous. M. Ames \& A.H. Kidd define Machiavellianism as a person's tendency to manipulate others in situations of interpersonal communication using subtle means, such as flattery, lies, bribery, and intimidation. In other works, this category is defined as a strategy of social behaviour that takes into account the manipulation of others for personal purposes, which often contradict their own goals. That is, Machiavellianism should be considered as a quantitative characteristic, since each of us is to some extent prone to manipulation, but some people are more inclined to it.

According to R.Christie \& F. Geis, theoretically and practically Machiavellianism constitutes a psychological syndrome based on a combination of interconnected cognitive, motivational, and behavioural characteristics. The key psychological components of Machiavellianism as a

${ }^{48}$ Karakulova O.V. Propensity to manipulate surrounding people in adolescence in the context of the problem of the formation of the "rigid type of personality". Bulletin of the Tomsk State University. 2009. No 320. P. 183.

${ }^{49}$ Machiavelli N. The Prince. Moscow: Planet, 1990. 79 p. 
personality trait is, firstly, one's conviction that when communicating with others he/she can and even should manipulate them; secondly, the specific skills to manipulate, the ability to persuade others, understand their intentions and causes of behaviour ${ }^{50}$.

Researchers S. Bogomaz and A. Makarenko suggest that the strategy of manipulation is based on a person's steady need for power, the content of which is a constant desire to influence people and put pressure on them through personal control of their actions ${ }^{51}$.

According to the described concept "Machiavellian" is identical to the concept of "manipulator" because Machiavellianism of a person means his/her tendency to manipulate. However, this identity does not include the definition of manipulation given by authors who believe that it can be implemented in the interests of the recipient for the best, altruistic reasons, whereas the Machiavellian acts only selfishly. In practice, it is extremely difficult to determine and compare the true motivation of the manipulator and the Machiavellian, which, in our opinion, can be deeply rooted in the unconscious sphere.

A Machiavellian is a person with a high tendency to manipulate, who is well able to influence others, and who considers this mode of behaviour to be quite acceptable. It is not about recognizing one's behaviour style as manipulative, because this concept is negative in the minds of most people, so not everyone agrees to call themselves a manipulator. The Machiavellian recognizes ways to achieve the goal, which can be called manipulative, as those that do not contradict his/her personality and are characteristic of most people.

J.R. Sparks found that individuals prone to manipulative behaviour tend to favour economic and social status values over moral and humanistic ones. This does not mean that the behaviour of individuals with high rates of Machiavellianism is always unethical. A Machiavellian does not openly show his/her desire for domination. His/her peculiarity is the attitude to the fact that one's significant goal can be more effectively achieved if one makes an "appropriate, right" impression on people and hides his/her true intentions ${ }^{52}$.

Empirical studies conducted during 2010-2017 revealed that the higher a person has a tendency to manipulate, the more valuable is the sphere of education, training, professional life for him/her, and the stronger the desire to

${ }^{50}$ Znakov V.V. Machiavellianism: the psychological property of a person and the technique of its research. Psychological Journal. 2000. No. 5. P. 16-17.

${ }^{51}$ Makarenko O.V., Bogomaz S.A. Personal characteristics of students-psychologists prone to manipulate others. Bulletin of TSU. "Psychology" Series. 2005. No. 286. P. 107.

${ }^{52}$ Makarenko O.V., Bogomaz S.A. Personal characteristics of students-psychologists prone to manipulate others. Bulletin of TSU. "Psychology" Series. 2005. No. 286. P. 107. 
not depend on the environment. It was also found that individuals who are especially clearly prone to manipulation are characterized by some fatalism and lack of confidence in their own ability to control and manage life ${ }^{53}$. This confirms the existentialists' opinion regarding the formation of a manipulative personality: insecurity and fear of uncontrolled events and people.

\section{CONCLUSIONS}

Awareness of the high effectiveness of covert influence for achieving one's goal and the gradual refinement of one's ability to influence others encourages a person to move from the use of scattered manipulative tactics to the development of manipulative strategies. When a person chooses manipulation as the dominant behavioural strategy, it indicates a pronounced tendency to manipulate as a persistent personality trait. Socio-cultural, technological, economic, socio-political prerequisites that are refracted through the prism of relationships within the family (reference group, teaching staff, etc.) as well as through a system of educative influences on a person, strengthen the personal disposition to manipulate.

\section{SUMMARY}

Summing up the results of the theoretical analysis, it is worth noting that manipulation can be a means of achieving a goal, in other cases, a person's goal in itself. In certain cases, manipulation is a justified and appropriate method. For example, a mother who needs to give a bitter medicine to a threeyear-old child is unlikely to be able to take advantage of the argument, especially if the only tangible effect of the intake is an unpleasant taste, and not the promised recovery. Pouring medication into a child's mouth by force can turn out to be worse - either half of it will be spilled, or the attempt will cause vomiting. Civilized influence (argumentation) was defeated, barbaric one (by force) as well. When the mother tells (most likely, invents) that the elder brother took this medicine with pleasure, and that right now she can go and give it to him, the child drinks the medicine quickly and without tears. The manipulation is based on the child's desire to imitate elders, as well as on age-related changes in the child's personality (in this case - to act to the contrary, to be the first).

Scientists emphasize that when a strategy to manipulate becomes predominant for a person in his/her interaction with other people, this impedes

\footnotetext{
${ }^{53}$ Hrabovska S., Hrebin N. Value-orientation sphere of persons prone to manipulation in interpersonal relationships. Problems of Modern Psychology: Collection of Research Papers of Kamianets-Podilskyi Ivan Ohienko National University, G.S. Kostiuk Institute of Psychology at APS of Ukraine / Ed. by S.D. Maksymenko, L.A. Onufriyeva. Issue 10. Kamianets-Podilskyi: Axioma, 2010. P. 167.
} 
personal development, because this person gradually loses the desire to experience positive emotions that arise in the process of communication ${ }^{54}$.

In any case, manipulation is a powerful weapon, regardless of the goals and intentions of the person who uses it. O. Sydorenko believes that the issue of the use of manipulation is a matter of individual moral choice. Each time a person must make decisions and bear full responsibility for his/her choice. No one can relieve a person of his/her individual responsibility for participating in manipulation $^{55}$.

\section{REFERENCES}

1. Аронсон Э., Пратканис Э.Р. Эпоха пропаганды: Механизмы убеждения, повседневное использование и злоупотребление. СанктПетербург: Прайм-Еврознак, 2003. 384 с.

2. Бабюк М.И. Социальная манипуляция (Философский анализ) Автореф. канд.. дисс. Москва, 2004. 19 с.

3. Бессонов Б.Н. Идеология духовного подавления. Москва.: вид-во МГУ, 1971.295c.

4. Волинець П.П. Критерії прихованого психологічного впливу. Екологічна психологія. 2010. Вип. 22. С. 15-20.

5. Гладышев С.А. Как выжить в толпе и остаться самим собой. Ростов на Дону: Феникс, 2004. 384 с.

6. Головаха Е.И., Панина Н.В. Психология человеческого взаимопонимания. Киев, 1989. 35 с.

7. Грабовська С., Гребінь Н. Ціннісно-орієнтацій на сфера осіб, схильних до маніпулювання у міжособистісних стосунках. Проблеми сучасної психології: Збірник наукових праџь Кам'янець-Подільського національного університету ім. Ів. Огієнка, Інституту психології ім. Г.С. Костюка АПН України. Вип. 10. Кам’янець-Подільський: Аксіома, 2010. C. $159-168$.

8. Грачев Г.В., Мельник И.К. Манипулирование личностью: организация, способы и технологии информационно-психологического воздействия. РАН. Ин-т философии. Москва, 1999. 235 с.

9. Гребінь Н.В. Мотиваційні установки осіб із схильністю до маніпулювання у міжособистісних стосунках. Проблеми сучасноі психології: Збірник наукових праць Камянець-Подільського національного університету ім. Івана Огієнка, Інституту психологї

\footnotetext{
${ }^{54}$ Makarenko O.V., Bogomaz S.A. Personal characteristics of students-psychologists prone to manipulate others. Bulletin of TSU. "Psychology" Series. 2005. No. 286. P. 108.

${ }^{55}$ Sidorenko E.V. Training on influence and resistance to influence. St. Petersburg: Rech. 2002. P. 59.
} 
ім. Г.С. Костюка АПН Украӥни. Вип.4. Камянець-Подільський: Аксіома, 2009. С. 39-48.

10. Доценко Е. Л. Психология манипуляции: феномены, механизмы и защита. Москва: ЧеРо, 1997. 344 с.

11. Каракулова О.В. Склонность к манипулированию окружающими людьми в юношеском возрасте в контексте проблемы формирования "ригидного типа личности". Вестник Томского государственного университета. 2009. № 320. С. 183-186.

12. Знаков В.В. Макиавеллизм: психологическое свойство личности и методика его исследования. Психологический журнал. 2000. № 5. C. $16-22$

13. Кабаченко Т.С. Методы психологического воздействия. Москва, $2000.544 \mathrm{c}$.

14. Лозниця С. Маніпуляція свідомістю: історико - культурні засади. Філософська думка. 2008. № 1. С. 142-155.

15. Макаренко О.В., Богомаз С.А. Личностные особенности студентов-психологов, склонных к манипулированию другими. Вестник ТГУ. Серия “Психология”. 2005. № 286. С. 105-109.

16. Макиавелли Н. Государь. Москва: Планета, 1990. 79 с.

17. Майерс Д. Социальная психология. Санкт-Петербург Мпб.: Питер, 2000. 688 с.

18. Сидоренко Е.В. Тренинг влияния и противостояния влиянию. СПб.: Речь, 2002. 256 с.

19. Татенко В.О. Психологія впливу: суб'єктна парадигма. Наукові студії із соціальної та політичної психології. Київ : Сталь, 2000. Вип. 3. C. $3-18$.

20. Дудинский Д.И. Тридцать способов манипуляции и управления людьми. Минск: Харвест, 2004. 96 с.

21. Фопель К. Уверенное управление. Тренинг, коучинг, саморазвитие. Москва: Генезис, 2004. 122 с.

22. Фром Э. Искусство любить. В кн.: Душа человека. М.: Республика, 1992. С. 109-178.

23. Хассен С. Освобождение от психологического насилия: деструктивные культы, контроль сознания, методы помощи. Санкт-Петербург.: Прайм-Еврознак, 2001. 400 с.

24. Чалдини Р. Психология влияния Санкт-Петербург: Питер, 2000. $272 \mathrm{c}$.

25. Шейнов В.П. Психология манипулирования. Минск: Харвест, 2009.704 c.

26. Шейнов В.П. Скрытое управление человеком. Психология манипулирования. Минск: Харвест, 2000. 848 с. 
27. Шостром Э. Анти - Карнеги, или Человек - манипулятор. Москва: Дубль-В, Дельта-92, 1998. 128 с.

28. Grebin, N. Psychological determinants of the individual's propensity to manipulate in interpersonal interactions. Journal of Education Culture and Society, 2020, 6(1), 108-119.

29. Riker, W. H. The Art of Political Manipulation. London : Yale University Press, 1986. 192 p.

Information about the authors: Hrebin N. V.,

Ph.D. in Psychological Sciences, Associate Professor Faculty of Philosophy, Department of Psychology Ivan Franko National University of Lviv 1, Universytetska str., Lviv, 79000, Ukraine https://orcid.org/0000-0002-9473-0404

Shyroka A.,

Ph.D. in Psychological Sciences, Associate Professor Faculty of Health Sciences, Department of Psychology and Psychotherapy Ukrainian Catholic University 17, I. Svientsitskoho str., Lviv, 79000, Ukraine https://orcid.org/0000-0002-5265-2794 